\title{
CYP27A1 wt Allele
}

National Cancer Institute

\section{Source}

National Cancer Institute. CYP27A1 wt Allele. NCI Thesaurus. Code C104150.

Human CYP27A1 wild-type allele is located within 2q35 and is approximately $34 \mathrm{~kb}$ in length. This allele, which encodes sterol 26-hydroxylase, mitochondrial protein, plays a role in bile synthesis and cholesterol homeostasis. Mutations in CYP27A1 are associated with cerebrotendinous xanthomatosis. 